\title{
Synthesis of 2-Halo-2H-Azirines from Phosphorus Ylides
}

\author{
Teresa M. V. D. Pinho e Melo,* António M. d'A. Rocha Gonsalves and Cládia S. J. Lopes \\ Departamento de Química, Faculdade de Ciencias e Tecnologia, Universidade de Coimbra, Portugal \\ Thomas L. Gilchrist \\ Chemistry Department, University of Liverpool, Liverpool L69 7ZD, UK
}

Received 28 September 1998; accepted 10 November 1998

\begin{abstract}
Oxophosphonium ylides (3m-3e) react with $N$-chlorosuccinimide and $N$-bromosuccinimide in the presence of azidotrimethylsilane giving the corresponding haloazidoalkenes ( $4 a-40$ ) with elimination of triphenylphosphine oxide. These compounds were completely converted to the $2 H$-azirines $5 \mathrm{~m}-\mathrm{S}_{\mathrm{g}}$ on heating in heptane. 1999 Elsevier Science Ltd. All rights reserved.
\end{abstract}

$2 H$-Azirines 1 are unsaturated three-membered heterocycles which are used for various synthetic purposes due to the high reactivity of such molecules. ${ }^{1}$ The most general method of synthesis of $2 H$-azirines is the thermal or photochemical decomposition of vinyl azides involving vinyl nitrenes as intermediates. ${ }^{1-4}$ There are very few literature reports of halo substituted azirines. ${ }^{3.4}$ The reaction of iodine azide $3 \mathrm{a}, \mathrm{b}$ or chlorine azide $^{3 c}$ with chloroalkenes followed by elimination of hydrogen iodide or hydrogen chloride gives the corresponding chlorovinyl azides which can be converted into chloroazirines $(1 \mathrm{a}-1 \mathrm{c})$. There are also a few examples of fluorinated $2 \mathrm{H}$-azirines, such as $2 \mathrm{a}$ and $2 \mathrm{~b}$, prepared from fluorovinyl azides. $4 \mathrm{a}, \mathrm{b}$ No bromo- $2 \mathrm{H}$ azirines have been reported before.

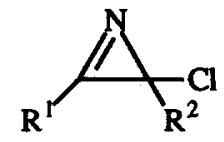

1a $\mathbf{R}^{1}=\mathbf{R}^{2}=\mathrm{Me}$

$1 b R^{1}=\mathrm{Ph} ; \mathrm{R}^{2}=\mathrm{Me}$

Ic $R^{1}=R^{2}=P h$

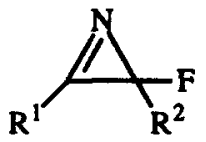

2a R $\mathbf{R}^{1}=\mathrm{F} ; \mathrm{R}^{2}=\mathrm{CF}_{3}$

2b $\mathbf{R}^{1}=\mathrm{CF}_{3} ; \mathbf{R}^{2}=\mathrm{F}$

In this paper we describe a new and general route to 2 -halo- $2 \mathrm{H}$-azirines starting from phosphorus ylides. We have recently reported the synthesis of tetrasubstituted alkenes by the reaction of phosphorus ylide 3a with chlorine and bromine in the presence of nucleophiles ${ }^{5}$ (Scheme 1). Similar reactions occur between ylide $3 \mathrm{a}$ and $N$-chlorosuccinimide and $N$-bromosuccinimide in the presence of methanol or azidotrimethylsilane.

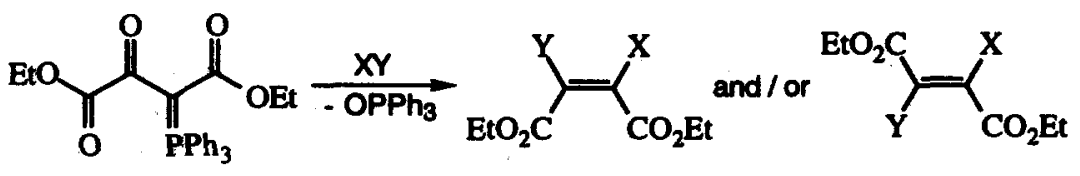

$3 a$

Scheme 1 
We postulated that isomeric halonium ions were intermediates in the formation of the observed products. These halonium ions could interconvert by way of an acyclic cation. The opening of the two halonium ions by a nucleophile would lead to the isomeric alkenes after the elimination of triphenylphosphine oxide (Scheme 2).

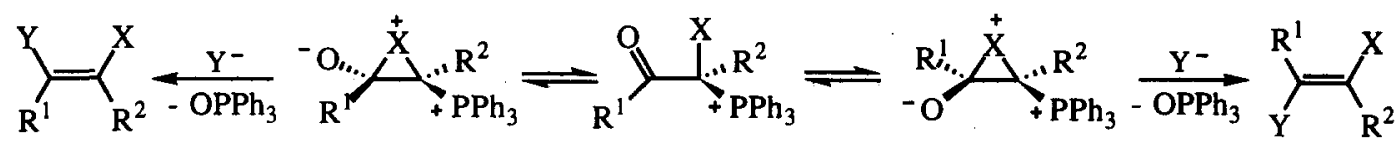

Scheme 2

Of particular interest is the possibility of preparing haloazidoalkenes from phosphorus ylides with $\mathrm{N}$ chlorosuccinimide and $\mathrm{N}$-bromosuccinimide in the presence of azidotrimethylsilane since these compounds are potential precursors of 2-halo- $2 \mathrm{H}$-azirines. In fact ylide 3a can be used to prepare alkenes $4 \mathrm{a} .{ }^{5}$ We decided to study the possibility of extending our reaction to other phosphorus ylides in order to obtain a range of haloazidoalkenes. Ylides $3 \mathbf{b}-3 \mathrm{e}^{6}$ were converted into the corresponding alkenes in good yield (Scheme 3). The products $4 \mathrm{~b}, 4 \mathrm{c}$ and $4 \mathrm{~g}$ were obtained as a mixture of $E / Z$ isomers whereas alkenes $4 \mathrm{~d}, 4 \mathrm{e}$ and $4 \mathrm{f}$ were obtained as single isomers. ${ }^{7}$<smiles>[R]C(=O)C([R])Pc1ccccc1</smiles>

3a $\mathrm{R}^{1}=\mathrm{R}^{2}=\mathrm{CO}_{2} \mathrm{Et}$

3b $\mathrm{R}^{1}=\mathrm{R}^{2}=\mathrm{CO}_{2} \mathrm{Me}$

3c $\mathrm{R}^{1}=\mathrm{Ph} ; \mathrm{R}^{2}=\mathrm{CO}_{2} \mathrm{Et}$

3d $\mathrm{R}^{1}=\mathrm{COPh} ; \mathrm{R}^{2}=\mathrm{CO}_{2} \mathrm{Me}$

3e $\mathrm{R}^{1}=\mathrm{Me} ; \mathrm{R}^{2}=\mathrm{CO}_{2} \mathrm{Me}$

$$
\underset{\mathrm{TMSN}_{3}}{\stackrel{\mathrm{NCS} \text { or NBS }}{\longrightarrow}} \quad \mathrm{R}^{1}\left(\mathrm{~N}_{3}\right) \mathrm{C}=\mathrm{C}(\mathrm{X}) \mathrm{R}^{2}
$$

4a $\mathrm{R}^{1}=\mathrm{R}^{2}=\mathrm{CO}_{2} \mathrm{Et} ; \mathrm{X}=\mathrm{Cl} \quad 90 \%$

4b $\mathrm{R}^{1}=\mathrm{R}^{2}=\mathrm{CO}_{2} \mathrm{Me} ; \mathrm{X}=\mathrm{Cl} \quad 75 \%$

4c $\mathrm{R}^{1}=\mathrm{R}^{2}=\mathrm{CO}_{2} \mathrm{Me} ; \mathrm{X}=\mathrm{Br} \quad 89 \%$

4d $\mathrm{R}^{1}=\mathrm{Ph} ; \mathrm{R}^{2}=\mathrm{CO}_{2} \mathrm{Et} ; \mathrm{X}=\mathrm{Cl} \quad 98 \%$

4e $\mathrm{R}^{1}=\mathrm{Ph} ; \mathrm{R}^{2}=\mathrm{CO}_{2} \mathrm{Et} ; \mathrm{X}=\mathrm{Br} \quad 60 \%$

4f $\mathrm{R}^{1}=\mathrm{COPh} ; \mathrm{R}^{2}=\mathrm{CO}_{2} \mathrm{Me} ; \mathrm{X}=\mathrm{Cl} \quad 40 \%$

$4 \mathrm{~g} \mathrm{R} \mathrm{R}^{1}=\mathrm{Me} ; \mathrm{R}^{2}=\mathrm{CO}_{2} \mathrm{Me} ; \mathrm{X}=\mathrm{Br} \quad 89 \%$

\section{Scheme 3}

Alkenes $4 \mathrm{a}-4 \mathrm{~g}$ are easily and completely converted into the corresponding $2 \mathrm{H}$-azirines $(5 \mathrm{a}-\mathbf{5 g})$ on heating in heptane for $2-3$ hours $^{8}$ (Scheme 4 ). The reaction can be followed by TLC and by IR by monitoring the disappearance of the band corresponding to the azido group of the starting azidoalkenes $(v \sim 2110-2120$ $\left.\mathrm{cm}^{-1}\right)$. The ${ }^{13} \mathrm{C}$ NMR spectra of the $2 H$-azirines show the $\mathrm{sp}^{2}$ carbon between 155 and $166 \mathrm{ppm}$ and the $\mathrm{sp}^{3}$ carbon between 43 and 63 ppm depending on the substitution pattern. Compounds $5 \mathrm{~b}$ and $5 \mathrm{f}$ show the signal for the $\mathrm{sp}^{3}$ carbon coincident with the signal for the methyl group (Table).

L'abbe et al. ${ }^{2}$ studied the thermolysis of dimethyl azidobutenedioate and found that starting from the $Z$ isomer only dimethyl $2 \mathrm{H}$-azirine-2,3-dicarboxylate was formed while the $E$ isomer gave a mixture of the azirine and methyl 5-methoxyisoxazole-3-carboxylate. However in our study we always obtained quantitative conversions of the alkenes which means that both isomers give the corresponding $2 \mathrm{H}$-azirine. 


$$
\mathrm{R}^{1}\left(\mathrm{~N}_{3}\right) \mathrm{C}=\mathrm{C}(\mathrm{X}) \mathrm{R}^{2} \underset{-\mathrm{N}_{2}}{\stackrel{\Delta}{\longrightarrow}}
$$

$4 a-4 g$<smiles>[R]C1=NC1([R])[X]</smiles>

5a $\mathrm{R}^{1}=\mathrm{R}^{2}=\mathrm{CO}_{2} \mathrm{Et} ; \mathrm{X}=\mathrm{Cl}$

5b $\mathrm{R}^{1}=\mathrm{R}^{2}=\mathrm{CO}_{2} \mathrm{Me} ; \mathrm{X}=\mathrm{Cl}$

Sc $\mathrm{R}^{1}=\mathrm{R}^{2}=\mathrm{CO}_{2} \mathrm{Me} ; \mathrm{X}=\mathrm{Br}$

5d $\mathrm{R}^{1}=\mathrm{Ph} ; \mathrm{R}^{2}=\mathrm{CO}_{2} \mathrm{Et} ; \mathrm{X}=\mathrm{Cl}$

Se $R^{1}=\mathrm{Ph} ; \mathrm{R}^{2}=\mathrm{CO}_{2} \mathrm{Et} ; \mathrm{X}=\mathrm{Br}$

5f $R^{1}=\mathrm{COPh} ; \mathrm{R}^{2}=\mathrm{CO}_{2} \mathrm{Me} ; \mathrm{X}=\mathrm{Cl}$

5 g $R^{1}=\mathrm{Me} ; \mathrm{R}^{2}=\mathrm{CO}_{2} \mathrm{Me} ; \mathrm{X}=\mathrm{Br}$

Scheme 4

Table ${ }^{13} \mathrm{C} \mathrm{NMR}$ in $\mathrm{CDCl}_{3}$ of the $2 \mathrm{H}$-azirines $5 \mathrm{a}-5 \mathrm{~g}$.

\begin{tabular}{ccc} 
Azirine & Yield & 13C NMR $(\delta$ in ppm $)$ \\
\hline 5a & $98 \%$ & $13.89,13.96,63.25(\mathrm{C}-2), 63.94,64.62,154.67(\mathrm{C}-3), 162.70$ and 165.36 \\
5b & $99 \%$ & $54.39,54.57\left(\mathrm{C}-2\right.$ and $\left.\mathrm{CH}_{3}\right), 155.02(\mathrm{C}-3), 162.58$ and 165.74 \\
5c & $98 \%$ & $42.90(\mathrm{C}-2), 54.48,155.01(\mathrm{C}-3), 163.11$ and 165.29 \\
5d & $97 \%$ & $13.94,53.99(\mathrm{C}-2), 63.23,119.56,129.55,130.72,134.96,163.52(\mathrm{C}-3)$ and 167.25 \\
5e & $97 \%$ & $14.06,44.19(\mathrm{C}-2), 63.56,119.78,129.78,130.94,135.09,164.51(\mathrm{C}-3)$ and 166.71 \\
5f & $97 \%$ & $54.37(\mathrm{C}-2$ and $\mathrm{CH} 3), 129.63,129.95,133.83,136.54,164.25,166.39(\mathrm{C}-3)$ and 179.06 \\
5g & $99 \%$ & $10.74,43.44(\mathrm{C}-2), 53.95,166.91(\mathrm{C}-3)$ and 167.49
\end{tabular}

This work has provided the synthesis of a range of isolable but unstable 2-halo- $2 \mathrm{H}$-azirines including 2-halo-2 $\mathrm{H}$-azirines bearing electron withdrawing groups at C-2 and C-3 (5a, 5b, 5c and 5n), 2-halo- $2 \mathrm{H}$-azirines bearing electron withdrawing groups at $\mathrm{C}-2$ and a phenyl at $\mathrm{C}-3$ (5d and 5e) and a 2-halo-2 $\mathrm{H}$-azirine derivative having an electron withdrawing group at $\mathrm{C}-2$ and a methyl group at C-3. Azirines with electron withdrawing groups at C-3 decomposed in the condensed phase within 2-3 days at room temperature whereas azirines with a phenyl or methyl group at $\mathrm{C}-3$ showed more stability. The route to halo- $2 \mathrm{H}$-azirines starting from phosphorus ylides presents itself as a very general method. 


\section{Acknowledgements:}

We thank Chymiotechnon and the Socrates Program for financial support.

\section{References and Notes}

1 Backes, J. in Methoden der Organischen Chemie (Houben-Weyl) 1992, E16, 316-369; b. Padwa, A. and Woolhouse, A. D. in Comprehensive Heterocyclic Chemistry, Pergamon Press, Vol. 7, 1984, 47-93.

2 L'abbé, G.; Dekerk, J.-P.; Van Stappen, P. Bull. Soc. Chim. Belg. 1981, 90, 1073-1074.

3 a. Ciabattoni, J.; Cabell, M. Jr. J. Am. Chem. Soc. 1971, 93, 1482-1483; b. Padwa, A.; Blacklock, T. J. ; Carlsen, P. H. J.; Pulwer, M. J. Org. Chem. 1979, 44, 3281-3287; c. Gallagher, T. C.; Sasse, M. J.: Storr, R. C. Chem. Commun. 1979, 419-420; d. Gallagher, T. C.; Storr, R. C. Tetrahedron Lett. 1981. 27, 29052908; e. Hamana, H.; Sugasawa, T. Chem. Lett. 1985, 571-574.

4 a. Banks, R. E.; McGlinchey, M. J. J. Chem. Soc. (C) 1970, 2172-2175; b. Banks, R. E.; Moore, G. J. J. Chem. Soc. (C) 1966, 2304-2307; c. Morawietz, J.; Sander, W. J. Org. Chem. 1996, 61, 4351-4354.

5 Rocha Gonsalves, A. M. d'A.; Cabral, A. M. T. D. P. V.; Pinho e Melo, T. M. V. D.; Gilchrist, T. L. Synthesis 1997, 673-676.

6 Ylide 3c was prepared as described in Aitken, R. A.; Hérion, H.; Janosi, A.; Raut, S. V.; Seth, S.; Shannon, I. J.; Smith, F. C. Tetrahedron Lett. 1993, 34, 5621-5622. Ylides 3b and 3d were prepared by the procedure described in reference 5 for ylide 3a; Ylide $3 \mathbf{e}$ was prepared as described in Wasserman, H. H.; Ennis, D. S.; Blum, C. A.; Rotello, V. M. Tetrahedron Lett. 1992, 33, 6003-6006.

7 General procedure for the synthesis of the alkenes: The ylide $(4.5 \mathrm{mmol})$ was dissolved in dichloromethane $(50 \mathrm{~mL})$ and a solution of azidotrimethyilsilane $(0.71 \mathrm{~g}, 6.5 \mathrm{mmol})$ and $N$ chlorosuccinimide or $N$-bromosuccinimide $(6.5 \mathrm{mmol})$ in dichloromethane $(100 \mathrm{~mL})$ was added. The reaction was complete after $5 \mathrm{~min}$. The residue obtained upon removal of the solvent was purified by column chromatography $\left(\mathrm{CH}_{2} \mathrm{Cl}_{2}\right)$ and gave the vinyl azide. Dimethyl 2-azido-3-chlorobutenedioate $4 \mathrm{~b}$ m.p. $48-50{ }^{\circ} \mathrm{C}$ (from pentane) (Found: $\mathrm{C}, 33.07 ; \mathrm{H}, 2.79 ; \mathrm{N}, 18.60 . \mathrm{C}_{6} \mathrm{H}_{6} \mathrm{ClN}_{3} \mathrm{O}_{4}$ requires $\mathrm{C}, 32.88 ; \mathrm{H}$, 2.74; $\mathrm{N}, 19.18 \%)$; $v(\mathrm{KBr}) 1678,1709,1721$ and $2137 \mathrm{~cm}^{-1} ; \delta\left(200 \mathrm{MHz}^{\left.-\mathrm{CDCl}_{3}\right)} 3.83(3 \mathrm{H}, \mathrm{s})\right.$ and 3.92 $(3 \mathrm{H}, \mathrm{s}) ; \delta\left({ }^{13} \mathrm{C}\right) 63.48,63.68,114.33,137.63,161.21$ and 162.34 .

8 General procedure for the synthesis of the azirines: A solution of the vinyl azide (2.0 mmol) in heptane $(10 \mathrm{~mL})$ was heated under reflux for $2-3 \mathrm{~h}$ (the reaction was monitored by TLC). The reaction mixture was cooled and the solvent evaporated giving the azirine. Methyl 2-bromo-2-methyl-2H-azirine-3carboxylate $5 \mathrm{~g}$ was isolated directly as an oil. $\delta\left(200 \mathrm{MHz} \mathrm{CDCl}_{3}\right) 2.58(3 \mathrm{H}, \mathrm{s})$ and $3.77(3 \mathrm{H}, \mathrm{s}) ; \delta\left({ }^{13} \mathrm{C}\right)$ $10.74,43.44,53.95,166.91$ and $167.49 ; m / z 208.9928\left[\mathrm{M}+\mathrm{NH}_{4}\right]^{+}\left(\mathrm{C}_{5} \mathrm{H}_{10} \mathrm{BrN}_{2} \mathrm{O}_{2}\right.$ requires $\left.\mathrm{M}, 208.9926\right)$. 